\title{
Quantifying the Potential of Renewable Natural Gas to Support a Reformed Energy Landscape: Estimates for New York State
}

\author{
Stephanie Taboada ${ }^{1,2}$, Lori Clark $^{2,3}$, Jake Lindberg ${ }^{1,2}$, David J. Tonjes ${ }^{2,3,4}$ and Devinder Mahajan ${ }^{1,2, *(1)}$ \\ 1 Department of Materials Science and Chemical Engineering, Stony Brook University, \\ Stony Brook, NY 11794, USA; stephanie.taboada@stonybrook.edu (S.T.); jake.lindberg@stonybrook.edu (J.L.) \\ 2 Institute of Gas Innovation and Technology, Advanced Energy Research and Technology, \\ Stony Brook, NY 11794, USA; lori.clark@stonybrook.edu (L.C.); david.tonjes@stonybrook.edu (D.J.T.) \\ 3 Department of Technology and Society, Stony Brook University, 100 Nicolls Rd, Stony Brook, NY 11794, USA \\ 4 Waste Data and Analysis Center, Stony Brook University, 100 Nicolls Rd, Stony Brook, NY 11794, USA \\ * Correspondence: devinder.mahajan@stonybrook.edu
}

\section{check for}

updates

Citation: Taboada, S.; Clark, L.; Lindberg, J.; Tonjes, D.J.; Mahajan, D. Quantifying the Potential of Renewable Natural Gas to Support a Reformed Energy Landscape: Estimates for New York State. Energies 2021, 14, 3834. https:// doi.org/10.3390/en14133834

Academic Editors: Fernando Rubiera González and Covadonga Pevida García

Received: 21 April 2021

Accepted: 21 June 2021

Published: 25 June 2021

Publisher's Note: MDPI stays neutral with regard to jurisdictional claims in published maps and institutional affiliations.

Copyright: (c) 2021 by the authors. Licensee MDPI, Basel, Switzerland. This article is an open access article distributed under the terms and conditions of the Creative Commons Attribution (CC BY) license (https:// creativecommons.org/licenses/by/ $4.0 /)$.

\begin{abstract}
Public attention to climate change challenges our locked-in fossil fuel-dependent energy sector. Natural gas is replacing other fossil fuels in our energy mix. One way to reduce the greenhouse gas (GHG) impact of fossil natural gas is to replace it with renewable natural gas (RNG). The benefits of utilizing RNG are that it has no climate change impact when combusted and utilized in the same applications as fossil natural gas. RNG can be injected into the gas grid, used as a transportation fuel, or used for heating and electricity generation. Less common applications include utilizing RNG to produce chemicals, such as methanol, dimethyl ether, and ammonia. The GHG impact should be quantified before committing to RNG. This study quantifies the potential production of biogas (i.e., the precursor to RNG) and RNG from agricultural and waste sources in New York State (NYS). It is unique because it is the first study to provide this analysis. The results showed that only about $10 \%$ of the state's resources are used to generate biogas, of which a small fraction is processed to RNG on the only two operational RNG facilities in the state. The impact of incorporating a second renewable substitute for fossil natural gas, "green" hydrogen, is also analyzed. It revealed that injecting RNG and "green" hydrogen gas into the pipeline system can reduce up to $20 \%$ of the state's carbon emissions resulting from fossil natural gas usage, which is a significant GHG reduction. Policy analysis for NYS shows that several state and federal policies support RNG production. However, the value of RNG can be increased 10-fold by applying a similar incentive policy to California's Low Carbon Fuel Standard (LCFS).
\end{abstract}

Keywords: renewable natural gas; biogas; fossil fuels; renewable energy; energy transformation; energy systems; energy assessment

\section{Introduction}

Global climate change, resulting from the use of fossil fuels to generate energy, is the defining issue of our times. The generation of energy is a locked-in technological system, but creating reforms to the existing structure is a difficult, albeit not impossible, matter [1]. Some have identified natural gas as a "bridge" energy source because it produces fewer emissions/kJ than other fossil fuels. As a result, its share of the United States energy mix has increased over the past decade [2,3]. "Greening" of the natural gas portion of fossil fuel energy production, by introducing zero-emission gas products, would be a means of reducing greenhouse gas (GHG) impacts from the energy system.

There are two substitutes for fossil fuel natural gas in the natural gas grid. One is hydrogen gas produced from the electrolysis of water. If the electrolysis is powered by solar or wind power, it provides a means of reducing the intermittency of these renewable energy sources and produces "green" hydrogen, meaning there are little-to-no GHG impacts [4]. 
However, the amount of "green" hydrogen that can be mixed into a natural gas system is $5-15 \%$ by volume [5].

The second low-carbon substitute for natural gas is renewable natural gas (RNG). Although the combustion of RNG releases carbon dioxide (i.e., unlike hydrogen combustion), it is considered "carbon neutral". This is because the carbon sources for RNG are part of the atmospheric carbon cycle, so their release does not add carbon to the atmosphere as fossil fuels do. However, the use of geologically sourced fuels releases large amounts of carbon, stored for millions to hundreds of millions of years, increasing the carbon in the atmosphere and, subsequently, increasing GHGs [6].

Biogas produced through the anaerobic digestion of organic material is the precursor to RNG. Biogas is typically $25 \%$ to $50 \%$ carbon dioxide and $50 \%$ to $75 \%$ methane, with minor amounts of nitrogen, hydrogen, ammonia, and hydrogen sulfide [7]. Biogas can be directly combusted for electricity generation, heat, or combined heat and power $(\mathrm{CHP})$ production [8]. Processing to remove hydrogen sulfide trace concentrations that corrode combustion engines is common [9]. Biogas has a long history of use as a fuel for cooking stoves and provides light in developing countries where electrical power is limited. Biomass is the primary resource utilized for biogas production. China had an extensive program to develop small network biogas production in the 1970s, and India is pursuing similar projects currently $[10,11]$.

Pipeline-grade RNG is produced from biogas through two steps. First, biogas purification removes harmful elements to the gas grid, such as siloxanes, which are abrasive, and hydrogen sulfide. Second, biogas upgrading removes most of the carbon dioxide, creating nearly pure methane by scrubbing out the carbon dioxide with water or organic solvents (i.e., polyethylene glycol), or by utilizing pressure swing adsorption with activated carbon or molecular sieves. The removal of carbon dioxide improves the heating value and density of the biogas, so it meets pipeline-grade specifications. These can vary, but generally, RNG must have a $95 \%$ or greater methane content to be interchangeable with pipeline-grade fossil natural gas [9]. Once it is created, RNG can be mixed into the existing natural gas pipeline system as a primary energy source and so it is less affected by technological lock-in than other renewable alternatives. RNG can be used as a fuel in the same applications as fossil natural gas (i.e., heat, electricity, CHP, and transportation) [12]. In the United States, it is more commonly used as a transportation fuel, such as liquified biomethane (LBM) or bio-compressed natural gas (bio-CNG) $[13,14]$. Less common applications of RNG include its utilization to produce platform chemicals, such as methanol, ammonia, and dimethyl ether (DME) [15].

The production and use of RNG have increased significantly, particularly in European countries, such as Sweden and Germany [16]. In Sweden, over half of the biogas is upgraded to RNG, mainly for transportation purposes [16]. It is worth noting that Sweden does not have access to a natural gas pipeline system, but has built up a refueling network in the southern half of the country and is expanding it into the northern part [17]. The RNG is transported as bio-CNG in mobile storage units, but other solutions, such as transporting it as LBM, are under development [17]. Germany is the largest biomethane producer in the world [18]. It produces biomethane predominantly for electricity generation and CHP generation [19]. Germany has announced that $10 \%$ of its natural gas consumption will be replaced with RNG in the gas grid by 2030 [16]. The RNG industry is greatly helped by Germany having a well-developed gas pipeline network all over the country [16]. In North America, the United States has a well-established RNG industry, driven predominantly by California [16,20].

Changing to renewable energy from technologically locked-in systems that utilize fossil fuels is difficult, even when the change seems relatively straightforward, such as substituting RNG for fossil natural gas. One way to incentivize switching to RNG is by improving the operational energy performance [21]. A study found that co-digestion with biomass or increasing the concentration of the feedstocks in the anaerobic digesters could be used to increase the overall efficiency [22]. Other methods for improving efficiency 
include replacing the conventional method of upgrading biogas with multistage membrane technology. It requires less energy, but produces a high RNG yield and high RNG recovery [23]. Germany, for example, predominantly uses membrane technology to upgrade biogas [19].

Change can also be promoted by pushes from externalities and pulled into place by government policies. The external push for change is clearly the existential threat of climate change. Several critical policies in the United States provide an impetus for the adoption of RNG as a pipeline substitute.

In 1978, the Public Utilities Regulatory Policy Act (PURPA) required utilities to purchase independent power generation at "avoided costs". The act was intended to increase the demand for energy sources other than imported oil, including renewable energy [24]. However, the restructuring of electricity markets in the 1990s reduced minimal production costs (i.e., commonly used for the avoided costs computation), leading to decreased market rates for renewable energy and lower negotiated rates for long-term contracts for alternate energy producers. This led to stagnation in renewable energy production. However, the market began to revive some, due to actions taken in individual states, such as creating net-metering programs, public benefits funds to support "green" energy, voluntary green energy purchase programs, and other subsidies and scattered tax credits. A federal production tax credit was also supportive [25].

A significant change occurred through the federal Energy Policy Act of 2005, especially the creation of Renewable Fuel Standards (RFS2) [26]. The act's overall intent was to reduce GHGs, expand the renewable fuels sector, and reduce reliance on imported fuels. Specifically, the RFS2 mandates that 36 million gallons of renewable fuel be added to the fuel pool by 2022 [26]. The standard will be met by requiring fuel producers to blend a certain number of gallons of renewable fuels into their current fuel supply [26]. The amount of renewable fuel each producer is expected to blend is known as the renewable volume obligation (RVO) [26]. The RVO of each producer is determined by how much of the total United States fuel capacity their production makes up [26,27]. The four renewable fuel categories are biomass-based diesel, cellulosic biofuel, advanced biofuel, and total renewable fuel [26]. Cellulosic biofuels refer to biofuels produced from cellulose, hemicellulose, or lignin [26]. In contrast, advanced biofuels refer to biofuels produced from renewable biomass (i.e., not including corn starch). Total renewable fuel includes corn starch ethanol [28,29].

The United States Environmental Protection Agency (EPA) enforces the RFS2. It created renewable identification numbers (RINs). RINs are credits generated when a producer produces a gallon of renewable fuel [26]. Fuel producers must purchase enough RINs to meet their RVOs [26]. Producers can also purchase RINs from other producers [26]. The need for producers to obtain RINs has created a market for their purchase, fostering the demand to produce renewable transportation fuels [26]. Biogas production facilities have been registered as RIN generators under the cellulosic biofuel and advanced biofuel categories [26]. The production of biogas earns 11.727 RINs/decatherm (1 decatherm $=1$ million Btu $=1.05$ million $\mathrm{kJ}=\sim 500 \mathrm{~m}^{3}$ biogas) $[29,30]$. The RINS associate with either biogas or RNG [26].

Three California policies have converted the state into the epicenter of the RNG industry. Two of them are the Renewable Energy Fund (REF) (1988) and the Renewable Portfolio Standard (RPS) (2003). The REF subsidizes in-state renewable energy producers and purchasers. The RPS requires $60 \%$ of retail electricity sales to come from renewable energy by 2030 and requires all the state's electricity to come from carbon-free resources by 2045 [31,32]. This increases California's demand for green power products and supports the overall RNG environment.

The third, which impacts producers outside of California more than the other two, is the Low Carbon Fuel Standard (LCFS). The purpose of the LCFS is to reduce the average carbon intensity (CI) of California transportation fuels by $20 \%$ by 2030 [33]. The CI of a fuel is defined as the amount of GHG emissions associated with its production, transportation, 
and consumption. It is typically measured in grams of carbon dioxide equivalent per megajoule $\left.\left(\mathrm{gCO}_{2} \mathrm{e} / \mathrm{MJ}\right)\right)$. Under the LCFS, the CI of retailed fuels in California must be reduced, or credits need to be purchased as an offset. The LCFS is managed and enforced by the California Air Resources Board (CARB). Transportation fuels in California must have lower CIs than CARB targets to produce LCFS credits. One LCFS credit equals one metric ton of carbon dioxide reduced. Fuels that have a low $\mathrm{CI}$ include ethanol, biodiesel, renewable diesel, compressed natural gas (CNG), liquefied natural gas (LNG), CNG and LNG derived from RNG, and hydrogen and electricity for electric vehicles [29]. Therefore, the LCFS has created a credit market for renewable fuels.

The programs work in concert because the RFS2 and LCFS incentivize the use of renewable fuels and generate LCFS credits that can then be sold in a market. Renewable fuels for transportation generate RINs and LCFS credits if it can be shown that the fuel is transported to, and used in, the transportation sector in California, specifically when the fuel has a lower CI score than the target established by CARB [29]. Thus, east coast RNG that could flow to California can generate RINs and LCFS credits that can be applied in the credit markets, enhancing the value of RNG above its base value as natural gas.

Most other states have adopted their own energy policies. For instance, New York State established its integrated energy policy in 2014, called Reforming the Energy Vision (REV). REV was amended in 2019 to increase its carbon release reduction goals. REV targets include the following:

- $\quad 40 \%$ reduction in GHG emissions from 1990 levels by 2030, $85 \%$ reductions by 2050;

- $50 \%$ of electricity to come from renewable energy resources by $2030,70 \%$ renewable by 2050;

- Zero carbon electric sector by 2040;

- 600 trillion Btu increase in statewide energy efficiency [34].

A core means to implement REV is the Clean Energy Standard (2016). It requires utility companies to procure $70 \%$ of the state's electricity from eligible clean energy sources by 2050 [35]. Biogas sources (i.e., anaerobic digesters or landfills) used to produce electricity qualify under the Clean Energy Standard [36].

Other legislation can promote biogas/RNG production. For instance, in 2019, New York State passed the Food Donation and Food Scraps Act. It mandates a phased adoption of source separation of food waste, beginning with large generators in 2022, and anticipates expanding the requirement to other generators subsequently. Although other management means, such as food donations, are listed above in the management hierarchy, anaerobic digestion is one means of meeting the requirements of the law. As a result, the law is anticipated to increase anaerobic digester development projects in New York State [37].

Our intention here is to describe the potential to reduce the GHG impact of natural gas through RNG production. RNG production and use are impacted by available gasgenerating stocks, technology choices, and policy environments, particularly to certain places and times. Therefore, we will ground our concepts by examining current and potential RNG production in New York State. Similar studies have been carried out for New Jersey, Long Island, NY, Chile, Poland, Italy, and many other regions. The study concerning Chile revealed that the forest and wood sector provided the largest biomethane potential and significantly reduced GHG emissions [38]. Poland's resource assessment showed a high RNG potential from its agricultural sector, municipal solid waste (MSW), and sewage sludge [39]. The study in New Jersey focused on potential RNG production from landfills and sewage sludge [40]. It showed that landfills can produce more RNG than sewage sludge and confirmed the potential for RNG production utilizing existing waste streams [40]. The study on Italy's RNG potential demonstrated that the agricultural sector can produce more than three times the domestic fossil natural gas production [41]. That is significant for Italy, a country dependent on imports for $78 \%$ of its energy consumption [41] The results of the Long Island, NY study revealed $234 \times 10^{6} \mathrm{~m}^{3}$ of RNG can be produced annually, generating $2.52 \mathrm{TW}$-h of power [42]. That is nearly $12 \%$ of the total electricity consumed on Long Island yearly [42]. The lessons learned from this study on New York 
State can be applied to draw broader conclusions regarding general prospects for RNG and the natural gas grid.

The rest of the study is organized as follows: Section 2 describes the method utilized to calculate the current and potential biogas and RNG production values. Section 3 discusses the potential biogas and RNG production from each resource. In contrast, Section 4 discusses the current biogas and RNG production from each resource. Finally, Section 5 provides a production summary for biogas and RNG, while Section 6 presents the conclusions.

\section{Materials and Methods}

Since the precursor of RNG is biogas, biogas production must first be calculated. Potential biogas production was calculated based on the production available for each resource in New York State, its volatile solids (VS) content, and its respective biogas yield. VS content is the organic material that can be converted into biogas. These values were collected from the literature and reports. Then, the potential RNG production for each resource was calculated. For example, the potential RNG from landfilled MSW was generated, assuming biogas is approximately $60 \%$ methane and RNG is $100 \%$ methane [42]. In other words, there is no loss of methane when upgrading from biogas to RNG [42]. The remaining feedstocks are anaerobically digested and contain, on average, $40 \%$ methane [43]. Therefore, RNG values for the remaining feedstocks were calculated, assuming biogas is $40 \%$ methane.

The current biogas and RNG production values were collected from sources such as the New York State Department of Environmental Conservation (NYSDEC), the Environmental Protection Agency (EPA), Water Environment Federation (WEF), and others.

\section{Resources for RNG Production in New York State}

Natural gas consumption in New York State in 2016 was the equivalent of 1335 TBtu, which converts to approximately $40 \times 10^{9} \mathrm{~m}^{3}$ [44]. If this were to be combusted with $100 \%$ efficiency, it would produce about $70 \times 10^{6}$ tons of carbon dioxide.

RNG can substitute fossil natural gas. However, the amount of RNG produced is dependent on the composition of the biogas, which varies according to the resources available locally. For instance, New York State does not produce sugar cane wastes (i.e., bagasse), which are a common stock for biogas facilities worldwide. The resources for biogas production assessed here include agricultural sources, such as cow manure, poultry manure, energy crops, other agricultural waste, and human-derived wastes, such as wastewater sludge, MSW landfills, food waste, yard waste, and paper mill waste [45]. The assessment includes the potential and current biogas and RNG production for New York State.

\subsection{Agricultural Sources}

The use of a single agricultural waste as feedstock in anaerobic digestion is not common. Instead, agricultural waste and livestock waste are typically mixed to reduce process inhibition, making the primary feedstock more digestible. Animal waste tends to increase methane yield and dilutes the production of substances that cause process upsets. Additionally, the introduction of enzymes and nutrients has been shown to increase biomethane potential [46].

New York State ranked third in the United States in dairy farming in 2016, with 620,000 dairy cows on 4420 farms $[47,48]$. Each cow produces 0.068 tons of manure per day [49]. Further, $20 \mathrm{~m}^{3}$ of biogas is produced per ton of cow manure, for a potential annual biogas generation of $3 \times 10^{8} \mathrm{~m}^{3}[50,51]$.

Chickens produce $80 \mathrm{~g}$ of manure per day. Ducks produce $150 \mathrm{~g}$ [52]. About $40 \mathrm{~m}^{3}$ of biogas is produced per ton of poultry manure [53]. In 2012, there were 7 million chickens and 225,000 ducks in New York State, a potential annual biogas generation of $1 \times 10^{7} \mathrm{~m}^{3}[48,54]$. 
Herbaceous energy crops, such as corn, sorghum, and soybeans, are grown in New York State. Other crops, such as miscanthus, switchgrass, poplar, and willow trees, are also grown in New York State. However, they are not used for commercial purposes (i.e., not quantified for New York State by the United States Department of Agriculture). A calculation of the annual biogas potential for herbaceous energy crops (Table 1) set the value at $3.3 \times 10^{9} \mathrm{~m}^{3}$.

Corn and sorghum can be used as grains for food consumption. However, their profitability as energy crops has caused farmers to divert from their original purpose, food, sparking a food versus fuel debate and tensions over land use [55]. Shifting from food to energy crops also impacts dairy and cattle production. For example, in the United States, more than $80 \%$ of agricultural output is utilized as animal feed [55]. With the inevitable growth of the global population, the demand for crops and meat will grow as well [55]. Meanwhile, land for growing crops is set to become increasingly scarce. Therefore, farming practices need to be improved to increase agricultural productivity to keep up with the demand for food and energy crops [55]. Genetic modification has been discussed to enhance agricultural productivity by making crops more pest-, salt-, and drought-resistant [55].

Table 1. Biogas production potential from energy crops in New York State.

\begin{tabular}{ccccc}
\hline Energy Crops & $\begin{array}{c}\mathbf{2 0 1 2} \text { Production } \\
\text { (Tons) }\end{array}$ & $\begin{array}{c}\text { VS Content } \\
\mathbf{( \% )}\end{array}$ & $\begin{array}{c}\text { Biogas Yield } \\
\left(\mathbf{m}^{\mathbf{3}} \mathbf{\text { ton }}\right)\end{array}$ & $\begin{array}{c}\text { Biogas Potential } \\
\mathbf{( m}^{\mathbf{3}} \mathbf{)}\end{array}$ \\
\hline Corn for grain & $2,227,126[48]$ & $96.57[56]$ & $325[57]$ & $699,000,000$ \\
Corn for silage & $8,230,187[48]$ & $96.57[56]$ & $325[57]$ & $2,580,000,000$ \\
Sorghum for grain & $617[48]$ & $92[58]$ & $334[57]$ & 189,000 \\
Sorghum for silage & $18,391[48]$ & $92[58]$ & $334[57]$ & $5,650,000$ \\
Miscanthus & NA & $32.7[59]$ & $186[59]$ & NA \\
Switchgrass & NA & $95.8[60]$ & $191[61]$ & NA \\
Poplar trees & NA & $77.3[62]$ & $127.2[62]$ & NA \\
Willow trees & NA & $97.8[63]$ & $200[64]$ & NA \\
Total & & & & $3.3 \times 10^{9}$ \\
\hline
\end{tabular}

Agricultural waste is produced when crops are grown for non-energy purposes. Common crop residues in New York State include corn stover, wheat straw, barley straw, oat straw, sorghum stubble, sunflower residue, and soybean straw (i.e., note that the anaerobic digestion of soybean straw and sunflower residues has not been studied) [65]. Crop straws and residues from the wood industry represent valuable biomass for the solid biofuel industry and subsequent production of syngas [66]. However, this downstream processing is not the focus of this review. Based on crop production data from the United States Department of Agriculture (USDA), the amount of crop residues that might be used for energy purposes was determined (see Appendix A). These data were then used to estimate the annual potential for biogas production for agricultural residues (Table 2), which is about $4 \times 10^{8} \mathrm{~m}^{3}$.

Table 2. Biogas production potential from agricultural residues in New York State.

\begin{tabular}{ccccc}
\hline $\begin{array}{c}\text { Agricultural } \\
\text { Residues }\end{array}$ & $\begin{array}{c}\text { 2012 Production } \\
\text { (Tons) }\end{array}$ & VS Content $\mathbf{( \% )}$ & $\begin{array}{c}\text { Biogas Yield } \\
\left(\mathbf{m}^{\mathbf{3}} \mathbf{\text { ton }}\right)\end{array}$ & $\begin{array}{c}\text { Biogas Potential } \\
\mathbf{( m}^{\mathbf{3}} \mathbf{)}\end{array}$ \\
\hline Corn stover & 942,314 & $90[67]$ & $420[68]$ & $356,000,000$ \\
Wheat straw & 85,450 & $94[69]$ & $400[27]$ & $32,000,000$ \\
Barley straw & 3778 & $97[70]$ & $230[71]$ & 843,000 \\
Oat straw & 26,204 & $86[27]$ & $670[27]$ & $15,000,000$ \\
Sorghum straw & 308 & $92[71]$ & $330[57]$ & 115,000 \\
Total & & & & $4 \times 10^{8}$ \\
\hline
\end{tabular}




\subsection{Municipal Waste Sources}

Waste sources for biogas production include sanitary wastes, undifferentiated solid wastes, food wastes, yard waste, and paper mill wastes.

Sanitary wastes are managed at wastewater treatment plants (WWTP). Since 2018, there were 625 industrial wastewater treatment plants (WWTPs) and 600 municipal WWTPs that processed a total of 97,347,125,748 L of wastewater per day in New York State [37,72]. Each $1000 \mathrm{~L}$ of wastewater produces about 0.0002 tons of sludge, which is 22,746 tons of sludge per day [73]. Generally, $5 \%$ of the sludge is total solids, and $65 \%$ of the total solids are VS. Therefore, New York State WWTPs should produce 1137 tons of total solids per day (739 tons of VS). One ton of VS produces about $210 \mathrm{~m}^{3}$ of biogas. Therefore, the total New York State WWTP potential biogas production is $150,000 \mathrm{~m}^{3} / \mathrm{d}\left(5.510^{7} \mathrm{~m}^{3} / \mathrm{yr}\right)$ [74].

Most disposed municipal solid waste (MSW) in the United States is managed through landfilling [75]. There were 27 active MSW landfills in New York State in 2017 [72]. All the MSW landfills are located at least $100 \mathrm{~km}$ north of New York City. MSW landfills no longer exist in New York City, since the Fresh Kills landfill closed in 2001. There have been no MSW landfills open on Long Island since 1995 due to the Long Island Landfill Law (1983). New York State generated close to 13 million tons of MSW in 2013; 42\% was landfilled (5,460,000 tons); the remaining 58\% was exported out of the state, recycled, or incinerated [75]. Long Island and New York City generate about $60 \%$ of New York State's MSW [76].

The organic fraction of landfilled MSW (OFMSW) is approximately $46 \%$ (i.e., food scraps, yard waste, wood, and process residues) [77], which is equivalent to 2,511,600 tons. OFMSW is landfilled upstate. Further, $200 \mathrm{~m}^{3}$ of biogas can be produced per ton of OFMSW [78], resulting in a potential annual biogas yield of $5 \times 10^{8} \mathrm{~m}^{3}$.

Solid waste policies are trending towards source separation of food waste, due to concerns regarding wasting food, and because landfilled food waste is thought to degrade rapidly before gas controls are in place, leading to fugitive methane releases as GHGs. Laws such as the Food Donation and Food Scraps Act [37] accelerate the adoption of new processes. USEPA [79] has created the following management hierarchy for food waste:

Source reduction (i.e., reduce the generation of food waste);

Feed hungry people;

Feed animals;

Industrial uses (i.e., waste oils or biogas production);

Composting;

Disposal (i.e., landfills or incineration).

Although biogas production is not the preferred means to manage food waste, it is the preferred engineering solution for food waste management. Food waste is estimated to be $30 \%$ of New York State's MSW. Therefore, 4,000,000 tons/yr of food waste might be available to digest and produce biogas. About half of these wastes are currently landfilled in New York State. The remainder is either incinerated or exported [76]. The potential amount of biogas produced from New York State's landfilled food waste is already accounted for in the potential annual biogas generated from OFMSW. If the incinerated or exported food waste instead were to be source-separated for anaerobic disposal, about 2,000,000 tons/yr would be available. The average digester gas production is about $110 \mathrm{~m}^{3} /$ ton of feedstock, less than that of solid waste, due to its water content [80]. Therefore, the potential annual biogas production from these wastes is equivalent to $2.2 \times 10^{8} \mathrm{~m}^{3}$.

Yard waste is an organic waste stream separated for management, primarily by composting in New York State (one million tons are composted each year) [76]. Yard waste is more degradable than undifferentiated solid waste, so the biogas generation estimate was $500 \mathrm{~m}^{3} /$ ton [81]. Therefore, if source-separated yard waste was diverted to anaerobic digestion, it would likely produce $5 \times 10^{8} \mathrm{~m}^{3} / \mathrm{yr}$ of biogas.

The United States is currently the second largest paper producer in the world, after China. Paper is used for written materials, packaging materials, and tissue and toilet paper. The demand for paper products has declined due to the emergence of electronic document 
distribution. This trend outweighs the growing use of paper packaging in delivered goods. As a result, United States producers have closed mills, with only two remaining in New York State (i.e., International Papers in Ticonderoga and Finch Paper in Glens Falls) [82,83]. Paper mills generate wastewater, which results in sludge production $(650 \mathrm{~L}$ sludge per ton of paper) [84]. The two mills generate approximately $2.3 \times 10^{9} \mathrm{~L}$ of sludge per year. Paper mill sludge is managed in the following two primary ways: burn it in a boiler to produce energy, or landfill it. Anaerobic digestion is also potentially possible, due to its organic nature and high moisture content $[85,86]$. Paper mill sludge produces $250 \mathrm{~m}^{3}$ of biogas per ton of VS, and there are $6.6 \times 10^{-2}$ tons of VS per $1000 \mathrm{~L}$ of sludge [87]. Thus, the potential annual production of biogas from paper mill sludge is $4 \times 10^{7} \mathrm{~m}^{3}$. Bio-oil and syngas can also be produced from paper mill sludge products, such as kraft lignin and black liquor, through hydrothermal liquefaction [88]. However, this downstream processing is not the focus of this review.

Another potential source of biogas from the paper mill industry is the wastewater produced from kraft pulping, a chemical pulping process [89]. However, New York State does not utilize this process in its paper mills. Therefore, estimates for biogas and RNG production from kraft pulping will not be included in this report.

\section{Current Biogas and RNG Production in New York State}

Two sectors have exploited available sources of biogas in New York State-dairy farms and landfills. However, they are different in their motivation. Dairy farm biogas use was fostered by explicit state financial support for the required digester infrastructure to create biogas. Landfills, beginning in the 1980s, had entrepreneurial exploitation of the existing landfill gas resource; this changed to regulatory compliance due to changes in the Clean Air Act in 1991.

\subsection{Agricultural Sector Use of Biogas}

There are 28 dairy farms in New York State $(43,000$ cows) with anaerobic digesters, and they have an estimated annual biogas production of $2 \times 10^{7} \mathrm{~m}^{3}$. Most of the sites use the "complete mix" technology, which is aboveground, heated, insulated, with round tanks where the waste is mixed using mechanical propellers with gas recirculation [90]. The systems were generally designed to generate electricity through onsite engines for direct use or to sell into the electrical grid. Some of the farms accept food and agricultural wastes or manage process waters from local food processors (i.e., typically dairy products) in addition to manure [79]. The economics of dairy farm electricity production is poor. New York State covered much of the capital cost of the digesters. In the absence of base electricity price supports for small generators, operational costs to either remove hydrogen sulfide and siloxanes, to minimize engine maintenance, or for the resulting maintenance needs exceed electricity revenues considerably. Digestion of manure makes the ensuing product easier to manage as a soil amendment in cropped fields or pasture, and controls site odors. That way, digester use continues at dairies that flare the produced gas [91].

In Aquebogue, Long Island, the Crescent Duck Farm is the only New York State poultry farm equipped with an anaerobic digester. The farm has approximately 130,000 ducks. The manure from the ducks is processed in a complete mix digester to produce about $9 \times 10^{5} \mathrm{~m}^{3}$ of biogas per year. Unfortunately, the gas is flared due to poor gas quality (i.e., the digester is used for waste volume reduction and odor control) [92].

No digesters in New York State are used solely for energy crops or crop residues. Instead, some crops and crop residues are used to supplement dairy and poultry manure as bulking agents. The produced biogas is accounted for under the animal manure amounts.

\subsection{Waste Sector Biogas and RNG}

There are 116 WWTPs in New York State that produce biogas. These plants generally operate at $7.5 \times 10^{9} \mathrm{~L} / \mathrm{d}$, below their total daily capacity of $10 \times 10^{9} \mathrm{~L} / \mathrm{d}$. Thus, the WWTPs produce approximately $4 \times 10^{6} \mathrm{~m}^{3} / \mathrm{yr}$ of biogas. Approximately two-thirds of the state's 
treatment capacity is in New York City (14 WWTPs), and they all produce biogas [93]. The biogas is mainly utilized to heat the digester, and for the CHP of the WWTPs [74].

Seventeen of the 28 active landfills capture landfill gas and use it to produce electricity. The total of biogas managed in this way is $4 \times 10^{8} \mathrm{~m}^{3} / \mathrm{yr}$ [72]. Several closed landfills generated electricity, but they no longer do because of the declining gas quality and reduced electricity reimbursement rates.

Two New York State landfills produce RNG. Seneca Meadows landfill, located in Seneca Falls, New York, produces biogas for electricity, and 70,000 $\mathrm{m}^{3} / \mathrm{yr}$ of RNG is used as vehicle fuel (i.e., $2500 \mathrm{~L} / \mathrm{d}$ of diesel fuel equivalents) [72,94,95]. Once the largest active landfill globally, Fresh Kills, located in Staten Island, New York, is now a park. It collects produced landfill gas and processes it to a little more than $4 \times 10^{7} \mathrm{~m}^{3}$ of pipeline-grade RNG annually. Because the local gas grid is connected to California, the site earns RINs and LCFS credits, generating $\$ 12$ million/yr (i.e., $90 \%$ from credits, 10\% from gas sales) $[96,97]$.

Food waste is typically co-digested with other feedstocks, such as animal manure, wastewater sludge, and agricultural residues. The biogas produced from co-digestion is credited to the predominant waste input. Five sites in New York State have food wastes as the primary input. They produced nearly $2 \times 10^{7} \mathrm{~m}^{3}$ of biogas in $2017[79,98-100]$.

There are no anaerobic digesters managing paper sludge in New York State. The technology is still theoretical, in that large quantities of lignocellulose lead to slow and incomplete hydrolysis during anaerobic digestion, which results in a longer retention time and a decline in degradation efficiency [101]. Different physical, chemical, and biological pretreatment methods for altering the lignocellulose content are currently being investigated [86].

\subsection{Planned Biogas/RNG Projects in New York State}

Two projects have been permitted, but are not yet constructed. American Organic Energy announced plans to build the first large-scale food digester facility on Long Island. It is expected to process around 180,000 tons of local food waste, 30,000 tons of fats, oils and greases, and 10,000 tons of grass clippings per year. The end uses of the biogas will be the production of 6.0 megawatts of electricity and vehicle fuel, possibly including RNG. The digestate will be processed for fertilizer and clean water. The project is slated to be operational by late 2020 [102-105]. New York City is working with National Grid (i.e., the local natural gas utility) to upgrade the $60 \%$ of biogas production at the Newtown Creek WWTP to RNG for pipeline injection. The remainder of the biogas is used to produce electricity onsite to power the plant. New York City's experience with the Fresh Kills landfill project makes the Newtown Creek WWTP project likely to be completed [100].

A related project is the Taylor Biomass Energy's biomass gasification plant in Montgomery, New York, which is permitted, but not yet constructed. The plant will pyrolyze MSW, construction and demolition waste, and wood waste, to produce synthesis gas (i.e., syngas). The project has received provisional certification from New York State as meeting tier 1 Renewable Energy Standard (RES) requirements, meaning the plant will produce renewable energy credits (RECs) for sale, to help New York State utilities meet its renewable energy goals [106].

\section{Discussion and Results}

\subsection{Anthropogenic Biogas/RNG Potential Summary for New York State}

Table 3 summarizes potential daily biogas and RNG production from agricultural and waste sources (i.e., anthropogenic biogas sources). Figure 1 provides a breakdown of potential RNG production by feedstock. Note that energy crops are the most significant potential source of biogas and RNG. Thus, areas with more crop agriculture than New York State could be well suited to creating robust RNG generation. For example, Germany, one of the world's leading biomethane and biogas producers, predominantly uses energy crops as its feedstock [18]. 
Table 3. Anthropogenic annual biogas generation potential in New York State.

\begin{tabular}{ccc}
\hline Feedstock & $\begin{array}{c}\text { Potential Biogas } \\
\text { Production } \mathbf{( m}^{\mathbf{3}} \mathbf{)}\end{array}$ & $\begin{array}{c}\text { Potential RNG } \\
\text { Production } \mathbf{( m}^{\mathbf{3}} \mathbf{)}\end{array}$ \\
\hline Dairy Manure & $3 \times 10^{8}$ & $1.2 \times 10^{8}$ \\
Poultry Manure & $1 \times 10^{7}$ & $4 \times 10^{6}$ \\
Energy Crops & $3.3 \times 10^{9}$ & $1.3 \times 10^{9}$ \\
Other Agricultural Residues & $4 \times 10^{8}$ & $1.6 \times 10^{8}$ \\
Total Agricultural Output & $4 \times 10^{9}$ & $1.6 \times 10^{9}$ \\
\hline Wastewater Sludge & $5.5 \times 10^{7}$ & $2.2 \times 10^{7}$ \\
Landfilled MSW & $5 \times 10^{8}$ & $3 \times 10^{8}$ \\
Other Food Waste & $2.2 \times 10^{8}$ & $8.8 \times 10^{7}$ \\
Currently Composted Yard Waste & $5 \times 10^{8}$ & $2 \times 10^{8}$ \\
Paper Mill Sludge & $4 \times 10^{7}$ & $1.6 \times 10^{7}$ \\
\hline Total Wastes Output & $1.3 \times 10^{9}$ & $6.3 \times 10^{8}$ \\
Total Anthropogenic Sources & $5.3 \times 10^{9}$ & $2.2 \times 10^{9}$ \\
\hline
\end{tabular}

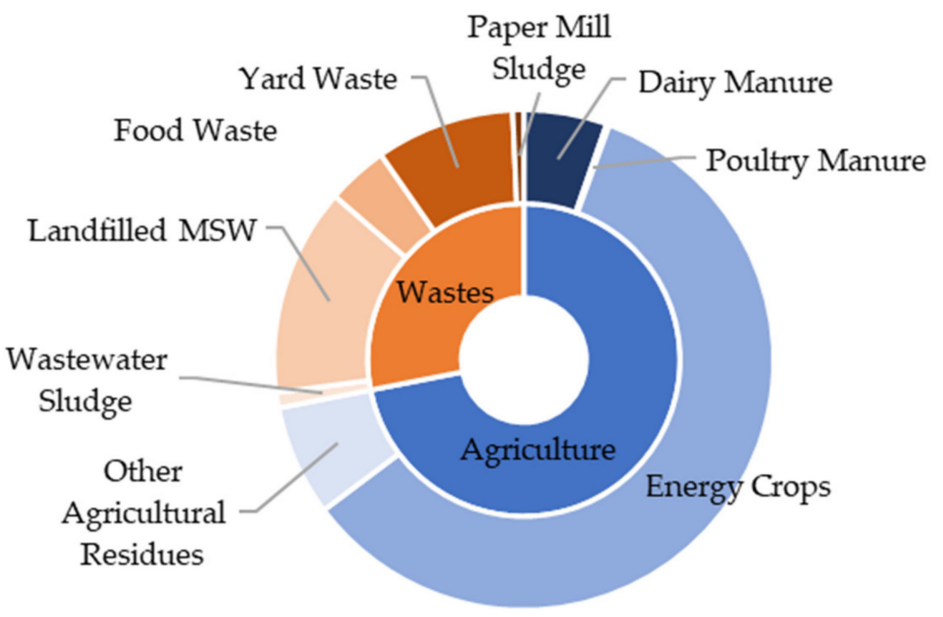

Figure 1. Anthropogenic annual RNG generation potential in New York State by feedstock.

Landfilled MSW is the second-largest source of RNG in New York State, followed by yard waste. In similar studies completed for New Jersey and Washington State, landfills were also one of the main sources for RNG [40,107].

Together, energy crops, landfills, and yard waste make up approximately $80 \%$ of the biogas and RNG potential for New York State. The other waste categories sum up to approximately as much as the landfilling generation rate for RNG. One-tenth of the overall biogas potential comes from specific energy cropping and about as much residues from New York State agriculture. Together, all manures and sludges have a potential biogas production rate that is $80 \%$ of the potential from New York State landfills.

Unfortunately, managing organic wastes through landfills is not environmentally sound, as small amounts of fugitive methane emissions cause GHG impacts that outweigh the potential environmental benefits from RNG production. This is because methane is 25-30 times greater in GHG impacts than carbon dioxide, on a 100-year time horizon, and is even less favorable on shorter time scales [6]. The diversion of OFMSW entirely to anaerobic digestion would result in greater RNG production, with better efficiencies than those realized at landfills. Studies show that the methane content in the biogas produced from the anaerobic digestion of OFMSW is always higher than 60\% [108]. Co-digestion of solid wastes at existing digestion facilities would increase production further, and is a currently favored management strategy. Gate fees from such combined operations cover the costs of electricity generation from biogas. If pipeline access is possible, conversion of the biogas to RNG should be much more profitable. 
The annual New York State consumption of natural gas is approximately $40 \times 10^{9} \mathrm{~m}^{3}$. The estimate here is that agricultural and waste sectors could potentially provide about $6 \%$ of this demand. New York State needs to change its practices in several important ways to achieve this, such as developing a robust energy crop industry, diverting yard waste away from composting, and re-directing OFMSW away from landfills to anaerobic digesters. Energy crop production is the most important, as it accounts for about $60 \%$ of the potential to produce biogas and RNG.

Replacing fossil natural gas with RNG produced from waste and agricultural sectors can reduce the annual carbon emissions associated with fossil natural gas use by approximately $6 \%$, which is equivalent to five million tons of carbon dioxide. This is about twice the current use of fossil natural gas for transportation, the putative use of RNG to optimize available economic subsidies. In addition, RNG used in conjunction with the substitution of "green" hydrogen for fossil natural gas can eliminate up to $20 \%$ of GHGs from the current fossil natural gas use in New York State.

Until this study, an analysis of a wide range of feedstocks available in New York State for producing RNG was never done. The information presented is essential so decisionmakers can implement policies focusing on feedstocks that produce the most significant amount of RNG, and to understand the impact RNG utilization can have on GHG emissions. For example, instead of prioritizing RNG production from WWTPs, decisionmakers can shift the focus to implementing policies that incentivize RNG production from large RNG-producing feedstocks, such as energy crops, OFMSW, and yard waste. Additionally, sewage sludge from WWTPs often contains contaminants introduced from domestic and industrial wastewater, so sewage sludge is often not ideal for producing biogas.

\subsection{Current Biogas/RNG New York State Production Summary}

The primary producers of biogas in New York State are landfills (Table 4). State regulations promote the recovery of biogas from landfills (i.e., current recovery of $80 \%$ ). Manure, food wastes, and WWTP sludges produce less than 5\% of the landfill output. All the current RNG produced in New York State is at landfills.

Table 4. Current annual biogas and RNG production for New York State.

\begin{tabular}{|c|c|c|c|}
\hline Feedstock & $\begin{array}{l}\text { Current Biogas } \\
\text { Production }\left(\mathrm{m}^{3}\right)\end{array}$ & $\begin{array}{c}\text { Current RNG } \\
\text { Production }\left(\mathrm{m}^{3}\right)\end{array}$ & $\begin{array}{l}\text { Potential RNG } \\
\text { Production }\left(\mathrm{m}^{3}\right)\end{array}$ \\
\hline Dairy Manure & $2 \times 10^{7}$ & & $1.2 \times 10^{8}$ \\
\hline Poultry Manure & $9 \times 10^{5}$ & & $4 \times 10^{6}$ \\
\hline Sum of Agricultural Output & $2 \times 10^{7}$ & & $1.2 \times 10^{8}$ \\
\hline Wastewater Sludge & $4 \times 10^{6}$ & & $2.2 \times 10^{7}$ \\
\hline Landfills & $4 \times 10^{8}$ & $2 \times 10^{7}$ & $3 \times 10^{8}$ \\
\hline Food Waste & $2 \times 10^{7}$ & & $8.8 \times 10^{7}$ \\
\hline Sum of Wastes Output & $4 \times 10^{8}$ & $2 \times 10^{7}$ & $4.1 \times 10^{8}$ \\
\hline Sum of Anthropogenic Sources & $4.2 \times 10^{8}$ & $2 \times 10^{7}$ & $5.3 \times 10^{8}$ \\
\hline
\end{tabular}

Although crop residues were previously identified as the greatest potential source of biogas in New York State, there is no significant utilization of the resource. While RNG has practical, environmental, and economic advantages for using biogas, only $10 \%$ of the generated biogas resource is currently upgraded to RNG.

If the technologically feasible feedstocks from Table 4 were entirely exploited as RNG, which seems economically advantageous, more than 10 times the current RNG production could be realized. The potential RNG production in Table 4 can make up approximately $1 \%$ of New York State's natural gas demand. Currently, transportation fuel use of fossil natural gas represents $2.5 \%$ of New York State's gas demand, meaning that exploited biogas production could meet approximately $50 \%$ of that demand. In other words, half of all New York State's natural gas used as transportation fuels could be "carbon emission-free." An 
example of the impact of implementing RNG as a transportation fuel can be witnessed in California, when in 2020, its natural gas vehicle fleet achieved carbon negative emissions for the first time [109]. It is estimated that by 2024, California-produced RNG for transportation will generate 3.4 million tons of GHG reductions annually [110].

\section{Conclusions}

RNG is eligible for various subsidies from the federal government and California, through clever application of replacement transportation fuel policies, increasing the value of the RNG by nearly an order of magnitude. The indirect cost from biogas contaminants (i.e., impacts to engines or costs to prevent those impacts) means electricity generation from biogas is often not economically favorable. Increasing the value of biogas through RINs and LCFS credits, by converting the biogas to RNG, seems to be an easily selected alternative.

The results of the study revealed the following for New York State:

- New York State collects about $10 \%$ of its potential biogas production;

- A small fraction of the current biogas production is processed to RNG, despite RNG being a technologically sound replacement for fossil natural gas;

- Energy crops can produce the most significant amount of RNG in New York State;

- Anaerobically digesting energy crops, OFMSW, and yard waste can produce nearly $80 \%$ of the potential RNG production calculated;

- About half of the RNG potential is technically feasible currently; it is also economically favored if RINs and LCFs credits can be captured;

- $20 \%$ of GHG emissions associated with fossil natural gas can be eliminated when replaced with RNG and "green" hydrogen.

Shifting energy systems to a more environmentally sound process is complex. However, currently, RNG is a means that can be easily applied from the energy use perspective, and appears economically and technically possible to expand, judging from the New York State example demonstrated here. Whether the impact is greater or less for other jurisdictions depends upon local factors, but the assessment of potential RNG production is not very difficult. This study provides a steppingstone for decisionmakers to begin this assessment and implement policies that support the anaerobic digestion of key feedstocks, followed by upgrading to RNG. Key feedstocks for New York State include energy crops, yard waste, and OFMSW.

Author Contributions: Formal analysis, S.T.; investigation, S.T.; resources, S.T.; data curation, S.T.; writing—original draft preparation, S.T.; writing—review and editing, S.T., D.M., D.J.T., J.L. and L.C.; All authors have read and agreed to the published version of the manuscript.

Funding: This work was supported by National Grid-US, through funding of the Stony Brook University's Institute of Gas Innovation and Technology (I-GIT).

Data Availability Statement: The data presented in this study are available on request from the corresponding author.

Acknowledgments: This work was supported by National Grid-US, through funding of the Stony Brook University's Institute of Gas Innovation and Technology (I-GIT). One of us (ST) acknowledge receipt of the GEM fellowship (2019-2020) and the Science Training and Research to Inform Decisions (STRIDE) fellowship (2020-2022) though the National Science Foundation Research Trainee (NRT) pro-gram. This is contribution \#6 of the Waste Data and Analysis Center, Stony Brook University.

Conflicts of Interest: The authors declare no conflict of interest.

$\begin{array}{ll}\text { Abbreviations } \\ \text { Bio-CNG } & \text { Bio-Compressed Natural Gas } \\ \text { CARB } & \text { California Air Resources Board } \\ \text { CHP } & \text { Combined Heat and Power } \\ \text { CI } & \text { Carbon Intensity }\end{array}$




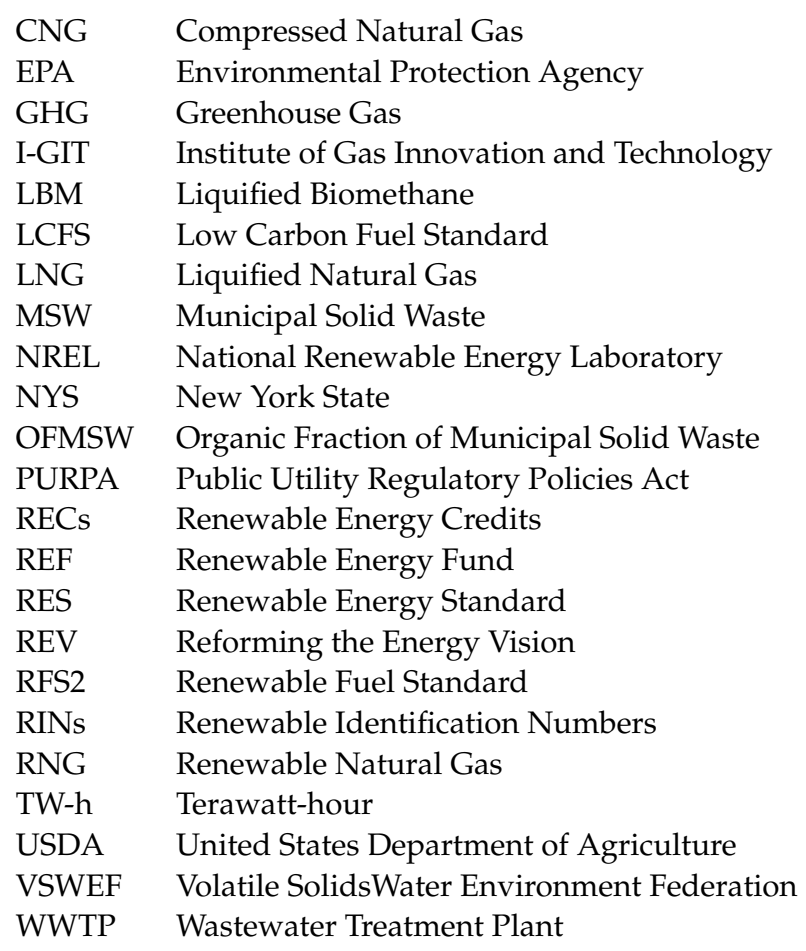

\section{Appendix A. Agricultural Residues Estimate}

The total amount of residues produced per crop was estimated based on 2012 USDA data, assuming that $50 \%$ of the residue produced would be used as cover for soil protection and other purposes, such as grazing and bedding [48].

Table A1. Agricultural residues estimate for New York State.

\begin{tabular}{|c|c|c|c|c|c|c|}
\hline Agricultural Crop. & $\begin{array}{c}2012 \text { Total Crop } \\
\text { Production } \\
\text { (Bushels/yr) [48] }\end{array}$ & $\begin{array}{l}\text { Bushel Weight } \\
\text { (lbs.) [67] }\end{array}$ & $\begin{array}{l}\text { Residue to Crop } \\
\text { Volume Ratio [67] }\end{array}$ & $\begin{array}{l}\text { Dry Matter } \\
\text { (\%) [67] }\end{array}$ & $\begin{array}{l}\text { Agricultural } \\
\text { Residue }\end{array}$ & $\begin{array}{l}2012 \text { Production } \\
\text { (Tons/yr) }\end{array}$ \\
\hline Corn for grain & $87,662,512$ & 56 & 1.0 & 84.5 & Corn stover & 940,956 \\
\hline Corn for silage & $8,230,187$ tons $/ y r$ & Not applicable & 1.0 & 33 & Corn stover & 1358 \\
\hline Wheat & $5,377,408$ & 60 & 1.35 & 96.5 & Wheat straw & 85,450 \\
\hline Barley & 338,294 & 48 & 1.2 & 85.5 & Barley straw & 3,778 \\
\hline Oat & $3,229,581$ & 32 & 1.3 & 86 & Oat straw & 26,204 \\
\hline Sorghum for grain & 24,290 & 56 & 1.4 & 88 & Sorghum straw & 380 \\
\hline
\end{tabular}

An example calculation for corn stover is shown.

$$
\begin{gathered}
\frac{56 \mathrm{lbs} \text { of corn }}{1 \text { bushel }} * 84.5 \% \text { dry matter }=\frac{47.32 \text { dry lbs of corn }}{1 \text { bushel }} \\
87,677,521 \text { corn } \quad \text { bushels } * \frac{47.32 \text { dry lbs of corn }}{1 \text { bushel }} * \frac{1 \text { lb of corn ctover }}{1 \text { dry lb of corn }} \\
* \frac{1 \mathrm{~kg}}{2.20462 \mathrm{lbs}} * \frac{1 \text { ton }}{1000 \mathrm{~kg}} * 50 \% \text { utilization } \\
=940,956 \text { tons of corn }
\end{gathered}
$$

\section{References}

1. Araújo, K. Low Carbon Energy Transitions: Turning Points in National Policy and Innovation; Oxford University: New York, NY, USA, 2017; ISBN 9780199362554.

2. United States Energy Information Administration. Available online: https://www.eia.gov/energyexplained/us-energy-facts/ (accessed on 16 June 2020).

3. Levi, M. Climate consequences of natural gas as a bridge fuel. Clim. Change 2013, 118, 609-623. [CrossRef] 
4. Pellegrini, M.; Guzzini, A.; Saccani, C. A Preliminary Assessment of the Potential of Low Percentage Green Hydrogen Blending in the Italian Natural Gas Network. Energies 2020, 13, 5570. [CrossRef]

5. Melaina, M.W.; Antonia, O.; Penev, M. Blending Hydrogen into Natural Gas Pipeline Networks. A Review of Key Issues; NREL/TP5600-51995; National Renewable Energy Laboratory (NREL): Golden, CO, USA, 2013. Available online: https://www.osti.gov/ servlets/purl/1219920 (accessed on 16 June 2020).

6. IPCC. Climate Change 2014: Synthesis Report; IPCC: Geneva, Switzerland, 2014; Available online: https://www.ipcc.ch/site/ assets/uploads/2018/05/SYR_AR5_FINAL_full_wcover.pdf (accessed on 16 June 2020).

7. Chai, X.; Tonjes, D.; Mahajan, D. Methane Emissions as Energy Reservoir: Context, Scope, Causes and Mitigation Strategies. Prog. Energy Combust. Sci. 2016, 56, 33-70. [CrossRef]

8. Wąs, A.; Sulewski, P.; Krupin, V.; Popadynets, N.; Malak-Rawlikowska, A.; Szymańska, M.; Skorokhod, I.; Wysokiński, M. The Potential of Agricultural Biogas Production in Ukraine-Impact on GHG Emissions and Energy Production. Energies 2020, 13, 5755. [CrossRef]

9. Abatzoglou, N.; Boivin, S. A review of biogas purification processes. Biofuels Bioprod. Biorefining 2009, 3, 42-71. [CrossRef]

10. Bond, T.; Templeton, M.R. History and future of domestic biogas plants in the developing world. Energy Sustain. Dev. 2011, 15, 347-354. [CrossRef]

11. Zuzhang, X. Domestic Biogas in a Changing China: Can Biogas Still Meet the Energy Needs of China's Rural Households? International Institute for Environment and Development: London, UK, 2013; Available online: https:/ / pubs.iied.org/16553IIED (accessed on 16 June 2020).

12. Savickis, J.; Zemite, L.; Bode, I.; Jansons, L.; Dzelzitis, E.; Koposovs, A.; Selickis, A.; Ansone, A. The Biomethane Injection into the Natural Gas Networks: The EU's Gas Synergy Path. Latv. J. Phys. Tech. Sci. 2020, 57, 34-50. [CrossRef]

13. Åhman, M. Biomethane in the transport sector-An appraisal of the forgotten option. Energy Policy 2010, 38, 208-217. [CrossRef]

14. Mintz, M. Renewable Natural Gas (RNG) for Transportation; Argonne National Laboratory: Lemont, IL, USA, 2020. Available online: https:/ / www.anl.gov/sites/www/files/2020-11/RNG_for_Transportation_FAQs.pdf (accessed on 6 June 2021).

15. Moghaddam, E.A.; Ahlgren, S.; Nordberg, Å. Assessment of Novel Routes of Biomethane Utilization in a Life Cycle Perspective. Front. Bioeng. Biotechnol. 2016, 4, 89. [CrossRef]

16. Koonaphapdeelert, S.; Aggarangsi, P.; Moran, J. Biomethane: Production and Applications; Springer Nature: Singapore, 2020; ISBN 9789811383076.

17. Backman, M.; Rogulska, M. Biomethane use in Sweden. Arch. Automot. Eng. Arch. Motoryz. 2016, 71, 7-19. [CrossRef]

18. Schmid, C.; Horschig, T.; Pfeiffer, A.; Szarka, N.; Thrän, D. Biogas Upgrading: A Review of National Biomethane Strategies and Support Policies in Selected Countries. Energies 2019, 12, 3803. [CrossRef]

19. Daniel-Gromke, J.; Rensberg, N.; Denysenko, V.; Stinner, W.; Schmalfuß, T.; Scheftelowitz, M.; Nelles, M.; Liebetrau, J. Current Developments in Production and Utilization of Biogas and Biomethane in Germany. Chem. Ing. Tech. 2018, 90, 17-35. [CrossRef]

20. Drake, J. Is RNG a California-Only Fuel? Available online: https://www.act-news.com/news/is-rng-a-california-only-fuel/ (accessed on 6 June 2021).

21. Pöschl, M.; Ward, S.; Owende, P. Evaluation of energy efficiency of various biogas production and utilization pathways. Appl. Energy 2010, 87, 3305-3321. [CrossRef]

22. Wang, M.; Lee, E.; Dilbeck, M.P.; Liebelt, M.; Zhang, Q.; Ergas, S.J. Thermal pretreatment of microalgae for biomethane production: Experimental studies, kinetics and energy analysis. J. Chem. Technol. Biotechnol. 2017, 92, 399-407. [CrossRef]

23. Scholz, M.; Melin, T.; Wessling, M. Transforming biogas into biomethane using membrane technology. Renew. Sustain. Energy Rev. 2013, 17, 199-212. [CrossRef]

24. DeCotis, P.A. PURPA Reform Implications for Utilities and Climate Change. Nat. Gas Electr. 2019, 36, 17-20. [CrossRef]

25. Taylor, M. Beyond technology-push and demand-pull: Lessons from California's solar policy. Energy Econ. 2008, 30, 2829-2854. [CrossRef]

26. Bracmort, K. The Renewable Fuel Standard (RFS): An Overview; Technical Report No. R43325; Congressional Research Service: Washington, DC, USA, 2020; Available online: https:/ /www.everycrsreport.com/files/20200414_R43325_1981cda6b9497b16f730 6b81d584cbcf91d4c801.pdf (accessed on 17 June 2020).

27. Zhao, Y.; Sun, F.; Yu, J.; Cai, Y.; Luo, X.; Cui, Z.; Hu, Y.; Wang, X. Co-digestion of oat straw and cow manure during anaerobic digestion: Stimulative and inhibitory effects on fermentation. Bioresour. Technol. 2018, 269, 143-152. [CrossRef]

28. United States Environmental Protection Agency. Available online: https:/ / www.epa.gov/renewable-fuel-standard-program/ overview-renewable-fuel-standard (accessed on 16 June 2020).

29. Whistance, J.; Thompson, W.; Meyer, S. Interactions between California's Low Carbon Fuel Standard and the National Renewable Fuel Standard. Energy Policy 2017, 101, 447-455. [CrossRef]

30. GreenTherm. GreenTherm ${ }^{\mathrm{TM}}$ : Voluntary Renewable Natural Gas Program Tehnical Confernce (19-057-T04) May 1, 2019. In Proceedings of the Voluntary Renewable Natural Gas Program Technical Conference; Salt Lake City, UT, USA, 1 May 2019. Available online: https:/ / pscdocs.utah.gov/gas/19docs/19057T04/307955TechConfPres5-1-2019.pdf (accessed on 16 June 2020).

31. California Public Utilities Commission. Available online: https:/ / www.cpuc.ca.gov/rps/ (accessed on 17 June 2020).

32. Allen, C.N. Untapped Renewable Energy Potential: Lessons for Reforming Virginia's Renewable Energy Portfolio Standard from Texas and California. Va. Environ. Law J. 2016, 35, 117-152. 
33. Christensen, A.; Hobbs, B. A model of state and federal biofuel policy Feasibility assessment of the California Low Carbon Fuel Standard. Appl. Energy 2016, 169, 799-812. [CrossRef]

34. New York State (NYS). Available online: https:/ / climate.ny.gov / (accessed on 5 June 2020).

35. New York State Energy Research Development Authority. Available online: https://www.nyserda.ny.gov/All-Programs/ Programs/Clean-Energy-Standard (accessed on 16 June 2020).

36. North Carolina Clean Energy Technology Center. Available online: http://programs.dsireusa.org/system/program/detail/93 (accessed on 16 June 2020).

37. New York State Department of Environmental Conservation (NYSDEC). Available online: https://www.dropbox.com/sh/hz3 spt98h4d88ue/AADmNLcYxcpZQFeWUNAxGMi9a?dl=0 (accessed on 5 June 2020).

38. Seiffert, M.; Kaltschmitt, M.; Miranda, J.A. The biomethane potential in Chile. Biomass Bioenergy 2009, 33, 564-572. [CrossRef]

39. Piechota, G.; Igliński, B. Biomethane in Poland-Current Status, Potential, Perspective and Development. Energies 2021, $14,1517$. [CrossRef]

40. Dyer, A.; Miller, A.C.; Chandra, B.; Maza, J.G.; Tran, C.; Bates, J.; Olivier, V.; Tuininga, A.R. The Feasibility of Renewable Natural Gas in New Jersey. Sustainability 2021, 13, 1618. [CrossRef]

41. Eyl-Mazzega, M.-A.; Mathieu, C. Biogas and Biomethane in Europe: Lessons from Denmark, Germany, and Italy; IFRI: Paris, France, 2019; Available online: https://www.ifri.org/sites/default/files/atoms/files/mathieu_eyl-mazzega_biomethane_2019.pdf (accessed on 6 June 2021).

42. Patel, S.; Tonjes, D.; Mahajan, D. Biogas potential on Long Island, New York: A quantification study. J. Renew. Sustain. Energy 2011, 3, 043118. [CrossRef]

43. Holliger, C.; Fruteau de Laclos, H.; Hack, G. Methane Production of Full-Scale Anaerobic Digestion Plants Calculated from Substrate's Biomethane Potentials Compares Well with the One Measured On-Site. Front. Energy Res. 2017, 5. [CrossRef]

44. New York State Energy Research and Development Authority. Patterns and Trends-New York State Energy Profiles: 2002-2016; New York State Energy Research and Development Authority: Albany, NY, USA, 2019. Available online: https://www.nyserda. ny.gov/about/publications/ea-reports-and-studies/patterns-and-trends (accessed on 16 June 2020).

45. Iglesias, R.; Muñoz, R.; Polanco, M.; Díaz, I.; Susmozas, A.; Moreno, A.D.; Guirado, M.; Carreras, N.; Ballesteros, M. Biogas from Anaerobic Digestion as an Energy Vector: Current Upgrading Development. Energies 2021, 14, 2742. [CrossRef]

46. Bhatnagar, N.; Ryan, D.; Murphy, R.; Enright, A.-M. Trace Element Supplementation and Enzyme Addition to Enhance Biogas Production by Anaerobic Digestion of Chicken Litter. Energies 2020, 13, 3477. [CrossRef]

47. McCarthy, D.; Canter, L.; Del Cogliano, D. 2019 New York State Dairy Statistics Report; New York State Department of Agriculture and Markets: Albany, NY, USA, 2019. Available online: https://agriculture.ny.gov/system/files/documents/2020/09/2019 dairystatisticsannualsummary.pdf (accessed on 16 June 2020).

48. Vilsack, T.; Clark, C.Z.F. 2012 Census of Agriculture AC-12-A-51; United States Department of Agriculture: Washington, DC, USA, 2014. Available online: https://www.nass.usda.gov/Publications/AgCensus/2012/Full_Report/Volume_1,_Chapter_1_US/ usv1.pdf (accessed on 16 June 2020).

49. PennState Extension. Available online: https:/ / extension.psu.edu/biogas-from-manure (accessed on 16 June 2020).

50. Ciborowski, P. Anaerobic Digestion of Livestock Manure for Pollution Control and Energy Production: A Feasibility Assessment; Minnesota Pollution Control Agency: St. Paul, MN, USA, 2001; Available online: https://www.pca.state.mn.us/sites/default/files/p-gen4 -02.pdf (accessed on 16 June 2020).

51. United States Environmental Protection Agency. Increasing Anaerobic Digester Performance with Codigestion; United States Environmental Protection Agency: Washington, DC, USA, 2012. Available online: https://www.epa.gov/sites/production/files/2014-1 2/documents / codigestion.pdf (accessed on 16 June 2020).

52. Mukhtar, S. Poultry Production: Manure and Wastewater Management. In Encyclopedia of Animal Sciences; Marcel Dekker: New York, NY, USA, 2005; pp. 744-747. Available online: https:/ /www.researchgate.net/profile/Saqib-Mukhtar/publication/2592 64250_Poultry_Production_Manure_and_Wastewater_Management/links/0c96052a9d93043929000000/Poultry-ProductionManure-and-Wastewater-Management.pdf (accessed on 16 June 2020).

53. Fulhage, C.D.; Sievers, D.; Fischer, J.R. Generating Methane Gas from Manure; Stanford University: Stanford, CA, USA, 1993; Available online: http:/ /large.stanford.edu/publications/power/references/docs/fulhage.pdf (accessed on 16 June 2020).

54. United States Department of Agriculture. Available online: https://www.nass.usda.gov/Quick_Stats/Ag_Overview/ stateOverview.php?state=NEW\%20YORK (accessed on 16 June 2020).

55. Graham-Rowe, D. Agriculture: Beyond food versus fuel. Nature 2011, 474, S6-S8. [CrossRef]

56. Colussi, I.; Cortesi, A.; Del Piccolo, C.; Gallo, V.; Rubesa Fernandez, A.S.; Vitanza, R. Improvement of Methane Yield from Maize Silage by a Two-stage Anaerobic Process. Chem. Eng. Trans. 2013, 32, 151-156.

57. Murphy, J.; Braun, R.; Weiland, P.; Wellinger, A. Biogas from Energy Crop Digestion. Available online: http:/ / task37.ieabioenergy. $\mathrm{com} /$ files/daten-redaktion/download/publications/Workshops/8/5-Energy_crops.pdf (accessed on 16 June 2020).

58. Jerger, D.E.; Chynoweth, D.P.; Isaacson, H.R. Anaerobic digestion of sorghum biomass. Biomass 1987, 14, 99-113. [CrossRef]

59. Whittaker, C.; Hunt, J.; Misselbrook, T.; Shield, I. How well does Miscanthus ensile for use in an anaerobic digestion plant? Biomass Bioenergy 2016, 88, 24-34. [CrossRef]

60. Niu, H.; Kong, X.; Li, L.; Sun, Y.; Yuan, Z.; Zhou, X. Analysis of biogas produced from switchgrass by anaerobic digestion. Bioresources 2015, 10, 7178-7187. [CrossRef] 
61. Bélanger, G.; Savoie, P.; Parent, G.; Claessens, A.; Bertrand, A.; Tremblay, G.; Massé, D.; Gilbert, Y.; Babineau, D. Switchgrass silage for methane production as affected by date of harvest. Can. J. Plant Sci. 2012, 92, 1187-1197. [CrossRef]

62. Yao, Y.; He, M.; Ren, Y.; Ma, L.; Luo, Y.; Sheng, H.; Xiang, Y.; Zhang, H.; Li, Q.; An, L. Anaerobic digestion of poplar processing residues for methane production after alkaline treatment. Bioresour. Technol. 2013, 134, 347-352. [CrossRef] [PubMed]

63. Gizińska-Górna, M.; Czekała, W.; Jóźwiakowski, K.; Lewicki, A.; Dach, J.; Marzec, M.; Pytka, A.; Janczak, D.; Kowalczyk-Juśko, A.; Listosz, A. The possibility of using plants from hybrid constructed wetland wastewater treatment plant for energy purposes. Ecol. Eng. 2016, 95, 534-541. [CrossRef]

64. Frigon, J.C.; Guiot, S.R. Biomethane production from starch and lignocellulosic crops: A comparative review. Biofuels Bioprod. Biorefining 2010, 4, 447-458. [CrossRef]

65. Kovačić, Đ.; Kralik, D.; Rupcic, S.; Jovičić, D.; Spajić, R.; Tišma, M. Soybean Straw, Corn Stover and Sunflower Stalk as Possible Substrates for Biogas Production in Croatia: A Review. Chem. Biochem. Eng. Q. 2017, 31, 187-198. [CrossRef]

66. Tian, F.; Xu, D.; Xu, X. Extruded Solid Biofuels of Rice Straw Plus Oriented Strand Board Residues at Various Proportions. Energies 2020, 13, 3468. [CrossRef]

67. Millbrandt, A. A Geographic Perspective on the Current Biomass Resource Availability in the United States; NREL/TP-560-39181; National Renewable Energy Laboratory: Golden, CO, USA, 2005. Available online: https://www.nrel.gov/docs/fy06osti/39181. pdf (accessed on 16 June 2020).

68. Liu, C.; Wachemo, A.C.; Tong, H.; Shi, S.; Zhang, L.; Yuan, H.; Li, X. Biogas production and microbial community properties during anaerobic digestion of corn stover at different temperatures. Bioresour. Technol. 2018, 261, 93-103. [CrossRef]

69. Rajput, A.A.; Visvanathan, C. Effect of thermal pretreatment on chemical composition, physical structure and biogas production kinetics of wheat straw. J. Environ. Manag. 2018, 221, 45-52. [CrossRef]

70. Schumacher, B.; Wedwitschka, H.; Hofmann, J.; Denysenko, V.; Lorenz, H.; Liebetrau, J. Disintegration in the biogas sectorTechnologies and effects. Bioresour. Technol. 2014, 168, 2-6. [CrossRef]

71. Zhang, Z.; Zhang, G.; Li, W.; Li, C.; Xu, G. Enhanced biogas production from sorghum stem by co-digestion with cow manure. Int. J. Hydrog. Energy 2016, 41, 9153-9158. [CrossRef]

72. New York State (NYS). Available online: https:/ / www.dec.ny.gov/lands/85861.html (accessed on 16 June 2020).

73. The National Research Council. Use of Reclaimed Water and Sludge in Food Crop Production; The National Academies Press: Washington, DC, USA, 1996; p. 192. ISBN 978-0-309-05479-9.

74. Wightman, J.; Woodbury, P. Current and Potential Methane Production for Electricity and Heat from New York State Wastewater Treatment Plants; New York State Water Resources Institute: Ithaca, NY, USA, 2014; Available online: https:/ /cpb-us-e1.wpmucdn.com/ blogs.cornell.edu/dist/2/7553/files/2017/08/Wightman2014_Current-and-potential-methane-production-for-electricityand-heat-1uqp5ry.pdf (accessed on 16 June 2020).

75. Staley, B.F.; Kantner, D.L. MSW Management in the US: 2010 \& 2013; Environmental Research \& Education Foundation: Raleigh, NC, USA, 2016; p. 63. Available online: https://erefdn.org/product/municipal-solid-waste-management-u-s-2010-2013/ (accessed on 16 June 2020).

76. DiNapoli, T. Local Governments and the Municipal Solid Waste Landfill Business; Office of the New York State Comptroller: Albany, NY, USA, 2018; p. 21. Available online: https:/ / www.osc.state.ny.us/localgov/pubs/research/landfills-2018.pdf (accessed on 16 June 2020).

77. United States Environmental Protection Agency. Advancing Sustainable Materials Management: 2016 and 2017 Tables and Figures; United States Environmental Protection Agency: Washington, DC, USA, 2019. Available online: https://www.epa.gov/sites/ production/files/2019-11/documents/2016_and_2017_facts_and_figures_data_tables_0.pdf (accessed on 16 June 2020).

78. Tyagi, V.K.; Fdez-Güelfo, L.A.; Zhou, Y.; Álvarez-Gallego, C.J.; Garcia, L.I.R.; Ng, W.J. Anaerobic co-digestion of organic fraction of municipal solid waste (OFMSW): Progress and challenges. Renew. Sustain. Energy Rev. 2018, 93, 380-399. [CrossRef]

79. United States Environmental Protection Agency. Available online: https://www.epa.gov/agstar/agstar-data-and-trends (accessed on 16 June 2020).

80. Arasova, L. Anaerobic Digestion of Food Waste: Current Status, Problems and an Alternative Product; Columbia University: New York, NY, USA, 2010; Available online: https: / / citeseerx.ist.psu.edu/viewdoc/download?doi=10.1.1.462.7158\&rep=rep1\&type=pdf (accessed on 16 June 2020).

81. Rathje, W.L.; Murphy, C. Rubbish! The Archeaology of Garbage, 1st ed.; HarperCollins: New York, NY, USA, $1992 ;$ ISBN 0816521433.

82. The Center for Paper Business and Industry Studies. Available online: http://www.paperstudies.org/millsonline/newyork.php (accessed on 16 June 2020).

83. Cohen, A. Paper Jam: Foreign Competition and Declining Demand for Paper will Plague Industry Mills; Technical Report No. 32212; IBISWorld: Los Angeles, CA, USA, 2017; Available online: https://www.wpr.org/sites/default/files/32212\%20Paper\%20Mills\% 20in\%20the\%20US\%20Industry\%20Report.pdf (accessed on 16 June 2020).

84. Do Carmo Precci Lopes, A.; Mudadu Silva, C.; Pereira Rosa, A.; De Ávila Rodrigues, F. Biogas production from thermophilic anaerobic digestion of kraft pulp mill sludge. Renew. Energy 2018, 124, 40-49. [CrossRef]

85. Kamali, M.; Gameiro, T.; Costa, M.E.V.; Capela, I. Anaerobic digestion of pulp and paper mill wastes-An overview of the developments and improvement opportunities. Chem. Eng. J. 2016, 298, 162-182. [CrossRef]

86. Veluchamy, C.; Kalamdhad, A.S. Influence of pretreatment techniques on anaerobic digestion of pulp and paper mill sludge: A review. Bioresour. Technol. 2017, 245, 1206-1219. [CrossRef] [PubMed] 
87. Priadi, C.; Wulandari, D.; Rahmatika, I.; Moersidik, S.S. Biogas Production in the Anaerobic Digestion of Paper Sludge. APCBEE Procedia 2014, 9, 65-69. [CrossRef]

88. Lappalainen, J.; Baudouin, D.; Hornung, U.; Schuler, J.; Melin, K.; Bjelić, S.; Vogel, F.; Konttinen, J.; Joronen, T. Sub- and Supercritical Water Liquefaction of Kraft Lignin and Black Liquor Derived Lignin. Energies 2020, 13, 3309. [CrossRef]

89. Ekstrand, E.-M. Anaerobic Digestion in the Kraft Pulp and Paper Industry: Challenges and Possibilities for Implementation; Linkoping Studies in Arts and Sciences: Linkoping, Sweden, 2019; Available online: https://www.diva-portal.org/smash/get/diva2: 1313936/FULLTEXT01.pdf (accessed on 19 May 2021).

90. United States Environmental Protection Agency. Combined Heat and Power Catalog of Technologies; United States Environmental Protection Agency: Washington, DC, USA, 2007; pp. 100-101. Available online: https:/ /www.epa.gov/agstar/project-profilenoblehurst-farms (accessed on 16 June 2020).

91. Usack, J.G.; Gerber Van Doren, L.; Posmanik, R.; Labatut, R.A.; Tester, J.W.; Angenent, L.T. An evaluation of anaerobic co-digestion implementation on New York State dairy farms using an environmental and economic life-cycle framework. Appl. Energy 2018, 211, 28-40. [CrossRef]

92. Harrington, M. Crescent Duck Farm is a Busy Operation in an Enviable Niche. Newsday 2018. Available online: https: / / www.newsday.com/business/crescent-duck-farm-long-island-1.20626397 (accessed on 16 June 2020).

93. Water Environment Federation (WEF). Available online: http://www.resourcerecoverydata.org/biogasdata.php (accessed on 16 June 2020).

94. Waste360. Available online: https://www.waste360.com/gas-energy/aria-energy-completes-expansion-rng-project-senecameadows-landfill (accessed on 16 June 2020).

95. Seneca Meadows Landfill. Available online: https:/ / senecameadows.com/gas-to-energy/ (accessed on 16 June 2020).

96. Ascher, K.; O'Connell, F. From Garbage to Energy at Fresh Kills. The New York Times, 15 September 2013. Available online: https:/ / archive.nytimes.com/www.nytimes.com/interactive/2013/09/15/nyregion/from-garbage-to-energy-at-freshkills.html(accessed on 16 June 2020).

97. NYC Department of Parks \& Recreation. Available online: https://www.nycgovparks.org/park-features/freshkills-park/aboutthe-site\#milestones (accessed on 16 June 2020).

98. New York State Department of Environmental Conservation. Buffalo Bioenergy Anaerobic Digestion System Facility Permit Description; DEC ID NO. 9-1468-00224; New York State Department of Environmental Conservation: New York, NY, USA, 2013. Available online: https: / / www.dec.ny.gov/dardata/boss/afs/permits/914680022400002.pdf (accessed on 16 June 2020).

99. New York State Department of Environmental Conservation. Niagara Bioenergy Anaerobic Digestion System Facility Permit Description; DEC ID NO. 9-2940-00191; New York State Department of Environmental Conservation: New York, NY, USA, 2013. Available online: https:/ / www.dec.ny.gov/dardata/boss/afs/permits/929400019100002.pdf (accessed on 16 June 2020).

100. NYC Department of Environmental Protection. Available online: http://www.nyc.gov/html/dep/html/press_releases/13-121 pr.shtml\#.W-kPRJNKhPY (accessed on 16 June 2020).

101. Jarnefeld, J. Benefical Uses of Paper Mill Residuals for New York State's Recycled-Paper Mills; Technical Report No. 95-15; New York State Energy Research and Development Authority: Albany, NY, USA, 1995; Available online: https://digital.library.unt.edu/ark: /67531/metadc625205/m2/1/high_res_d/119919.pdf (accessed on 16 June 2020).

102. Area Development. Available online: https://www.areadevelopment.com/newsItems/3-22-2019/long-island-power-authorityamerican-organic-energy-yaphank-new-york.shtml (accessed on 16 June 2020).

103. The New York Times Sunday Magazine. Available online: https://www.nytimes.com/2017/02/15/magazine/the-compostking-of-new-york.html (accessed on 18 December 2020).

104. American Organic Energy. Available online: https://www.usbiopower.com/organic-energy/anaerobic-digester (accessed on 16 June 2020).

105. The Coalition for Renewable Natural Gas. Available online: https://docs.google.com/spreadsheets/d/1CpLTd1Yya4 qQzUpWYtKMUGW1BlMmn-Jrj3uErd81J7A/edit\#gid=0 (accessed on 16 June 2020).

106. Times Hudson Valley. Available online: http://timeshudsonvalley.com/stories/taylor-biomass-facility-gains-tier-1-status,3527? (accessed on 16 June 2020).

107. Jensen, J. Biomethane for Transportation: Opportunities for Washington State; Washington State University Extension Energy Program: Spokane, WA, USA, 2011; Available online: https://research.libraries.wsu.edu/xmlui/bitstream/handle/2376/5952/ Biomethane_For_Transportation_WWCleanCities.pdf?sequence=1\&isAllowed=y (accessed on 6 June 2021).

108. Novarino, D.; Zanetti, M.C. Anaerobic digestion of extruded OFMSW. Bioresour. Technol. 2012, 104, 44-50. [CrossRef] [PubMed]

109. Biomass Magazine. Available online: http://biomassmagazine.com/articles/17518/rng-helps-reach-carbon-negative-milestonein-california (accessed on 6 June 2021).

110. Gladstein, C.; Patrick, C. An Assessment: California's In-State RNG Supply for Transportation 2020-2024; Gladstein Neandross \& Associates: Santa Monica, CA, USA, 2020; Available online: https:/ / cdn.gladstein.org/pdfs/whitepapers/report-assesmentcalifornia-in-state-rng.pdf (accessed on 6 June 2021). 